\title{
HDV GENOTYPES IN THE WESTERN BRAZILIAN AMAZON REGION: A PRELIMINARY REPORT
}

\author{
RAYMUNDO PARANÁ** ALAN KAY, FELIX MOLINET, SEBASTIÃO VIANA, LUCIANO KALABRIC SILVA, \\ JUAN MIGUEL SALCEDO, JOSÉ TAVARES-NETO, CIRLEY LOBATO, MÁRCIO RIOS-LEITE, LUCIANA MATTEONI, \\ ARGEMIRO D' OLIVEIRA JR, PEDRO TAUIL, AND CHRISTIAN TRÉPO \\ Gonçalo Moniz Research Center, Salvador, Brazil; INSERM Unit 271, Université Claude Bernard Lyon 1, IFR 62, Lyon, France; \\ Tropical Medicine Unit, University of Brasilia, Brasilia, Brazil; Government of Acre State-Health Secretariat, Rio Branco, Brazil; \\ Tropical Medicine Center, Porto Velho, Brazil
}

\begin{abstract}
In Brazil, hepatitis delta virus (HDV) is only reported in Western Amazonia, where severe cases of acute and chronic HDV hepatitis have been described. The study area was chosen in the States of Acre and Rondonia where most cases of hepatitis B virus (HBV)/HDV are reported. From December 2003 to October 2004, 40 HBsAg carriers with anti-HDV IgM were selected. An epidemiologic questionnaire, including demographic and clinical/epidemiologic variables was filled out. HDV amplification and genotyping were performed. Genotype I was detected in 22 patients $(55.0 \%)$, whereas genotype III was identified in 18 (45.0\%). Patients who were infected with genotype I were older $(45.1$ \pm 17.8 years) than patients infected with genotype III $(32.8 \pm 10.9$ years; $P=0.01)$. No symptoms were reported by 21 $(52.5 \%)$ patients. Otherwise, 19 (47.5\%) had symptoms (fatigue, abdominal pain, weight loss, and decompensated liver disease) that motivated them to seek medical care. Genotype III carriers were more symptomatic, but no statistical significance was achieved. Our preliminary results show that HDV genotypes I and III are present in Brazilian Amazonia and that HDV genotype III is not limited to the Amerindian population.
\end{abstract}

\section{INTRODUCTION}

The hepatitis delta virus (HDV) is a unique human virus that is associated with co-infections with hepatitis B or superinfections of hepatitis B virus (HBV) carriers. It was first described by Rizzetto and others in $1977 .^{1}$

The prevalence of HDV varies largely depending on the geographic areas. In some Mediterranean regions, Africa, and the Middle East, up to $24 \%$ of HBsAg carriers present HDV markers. On the other hand, this infection is uncommon in the United States, where it is basically restricted to high-risk groups such as drug users and hemophiliacs. ${ }^{2}$ In Brazil, HDV is only reported in Western Amazonia, where severe cases of acute and chronic HDV hepatitis have been frequently described. ${ }^{3,4}$ In this region, the percentage of HBsAg carriers with anti-HDV antibodies can reach $32 \% .^{5,6}$

Genetic and sequencing studies of the genomes of HDV reveal a high heterogeneity of this virus, which has been classified into three genotypes: I, II, and III. ${ }^{7,8}$ Genotype II has been further subdivided into subtypes (II, IIa, IIb). In a recent study, phylogenetic analysis including a large number of new strains from Africa suggested that there are more than three HDV genotypes. ${ }^{9}$ Each genotype of HDV has a different geographic distribution and association with severity of liver disease. Genotype III and subtype IIa are considered to be the most pathogenic. $^{10}$

In the westernmost Amazonian basin of Brazil, although referral centers for tropical medicine frequently report severe acute and chronic cases of $\mathrm{HDV} / \mathrm{HBV}$, there is a paucity of detailed clinical and biomolecular studies (data from the epidemiologic surveillance reports of the Health Secretary Office of the State of Acre). In other Amazonian countries, HDV genotypes I and III prevail, but it is mainly genotype III that seems to cause severe acute and chronic hepatitis. ${ }^{11,12}$

These findings justify this study on delta hepatitis in the

*Address correspondence to Raymundo Paraná, Av. Juracy Magalhaes Jr 2096, Sala 510, Salvador, Bahia 41920000, Brazil. E-mail: rparana@ufba.br
Brazilian Western Amazonia that aims to contribute to a better understanding of the molecular epidemiology and clinical aspects of HDV infections in Brazil.

\section{MATERIALS AND METHODS}

Study area. The study area was chosen in the State of Acre and the State of Rondonia, where most cases of HBV/HDV are reported to the Brazilian Health Ministry (Figure 1).

Patients from two referral centers for viral hepatitis in Rio Branco (capital of the state of Acre) and Porto Velho (capital of the state of Rondonia) who were anti-HDV IgG positive and undergoing anti-viral treatment were included.

In this area, local clinical observations by general practitioners indicated many cases of chronic hepatitis and cirrhosis caused by HDV/HBV infections, as well as outbreaks of fulminant hepatitis.

Study population. All HBV carriers (702) referred to both centers between December 2003 and October 2004 were evaluated for anti-HDV IgG and/or IgM. Most of these patients had been diagnosed for hepatitis B from serology tests requested by the local general practitioners because they lived in a highly endemic area where an epidemiologic survey for hepatotropic viruses was being conducted. Anti-HDV IgM was found in $40 \mathrm{HBs} A g+$ patients and all were $\mathrm{HDV}$ RNA positive. Twelve other patients had anti-HDV IgG with no HDV RNA. Only those patients positive for HDV RNA were included for further study. Only naive HBV carriers (no history of antiviral treatment) were included. No anti-HCV was identified in these patients.

After reviewing the medical files, an epidemiologic questionnaire, including demographical data (age, sex, place of birth, origin, occupation, etc.) was established. Files from patients were updated to get more detailed epidemiologic and clinical information.

Race was categorized into Amerindians, consisting of Indians and mixed-race Indians, and non-Amerindians, consisting of African descendants and whites.

Symptomatic HDV infection was defined as the presence of symptoms and signs that motivated patients to seek medical 


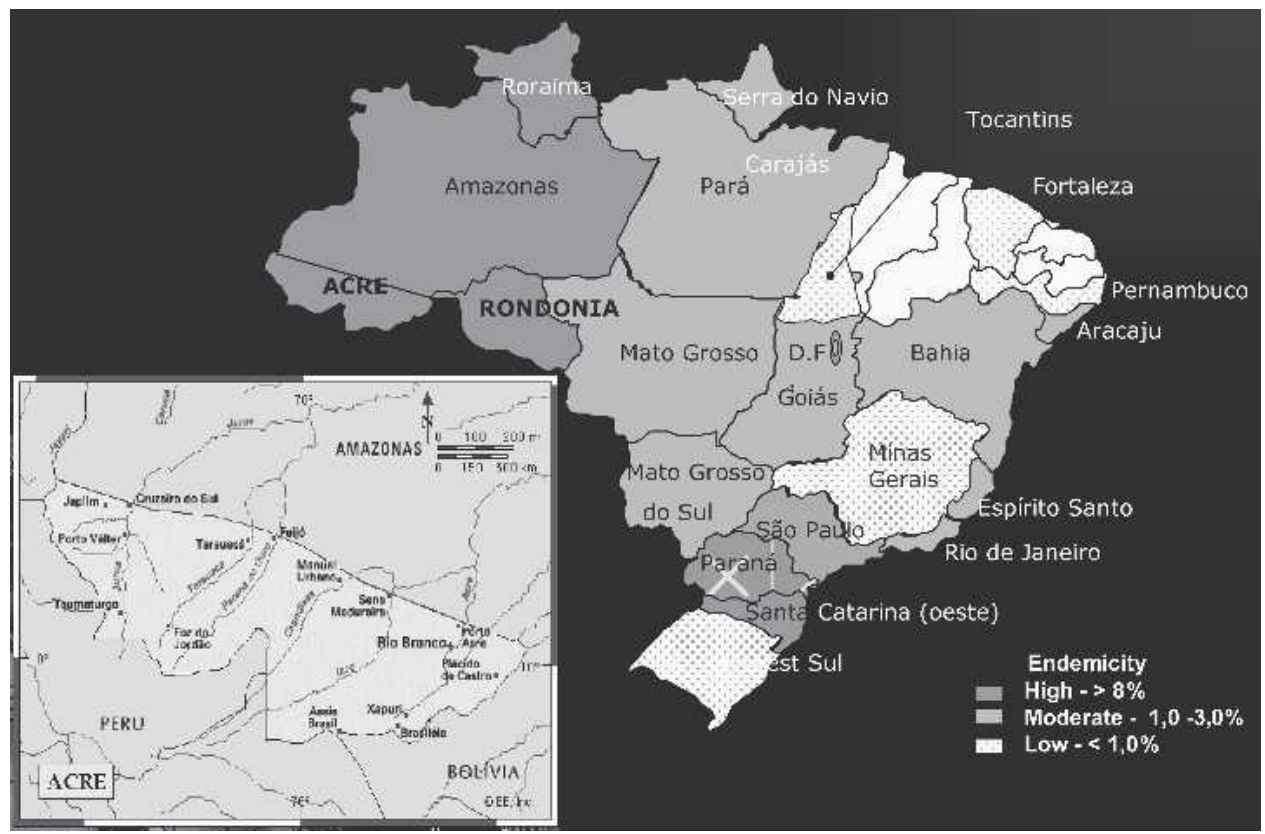

FIGURE 1. HBsAg prevalence in Brazil. Acre and Rondonia States in the Western Amazonia of Brazil are areas of high endemicity.

care and/or of classic signs/symptoms of decompensated liver disease. Asymptomatic patients were defined as those who had been identified only by the serological tests requested by general practitioners and who showed no signs or symptoms associated with chronic liver disease.

Serological markers. Serological markers for HDV and HBV were determined using commercial kits (ELISA, Dia Sorin, Italy). Anti-HCV was performed using commercial kits from Roche (Basel, Switzerland). All selected patients were tested for the following serological markers: anti-HCV, anti$\mathrm{HBc} \mathrm{IgG}, \mathrm{HBsAg}$, and anti-HDV IgG and IgM.

HDV amplification and genotyping. Total nucleic acids were extracted from $200 \mu \mathrm{L}$ of serum using the High Pure Viral Nucleic Acids kit (Roche Diagnostics, Meylan, France). An extraction control (phosphate-buffered solution) was also included. Samples were eluted in $50 \mu \mathrm{L}$ of elution buffer. A 981-bp HDV fragment was amplified (total reaction volume $50 \mu \mathrm{L}$ ) from $5 \mu \mathrm{L}$ of extract by reverse transcriptasepolymerase chain reaction (RT-PCR; OneStep RT-PCR kit; Qiagen, Courtaboeuf, France) using two primers selected from well conserved regions of HDV and capable of amplifying HDV of all genotypes. This fragment contains both of the delta ribozymes and the C-terminal half of the delta antigen(s) ORF. A 387-bp fragment was amplified by seminested PCR, using the same anti-sense primer as in the RTPCR and an internal sense primer, again chosen from a conserved region near the end of the anti-genomic ribozyme sequence. This fragment also contains the C-terminal half of the delta antigen(s) ORF. A negative control (water) was included in both the RT-PCR and semi-nested PCR. The products of the RT-PCR and semi-nested PCR $(10-\mu \mathrm{L}$ aliquots) were electrophoresed on $1 \%$ agarose gels and transferred to nylon membranes. The membranes were successively hybridized with two ${ }^{32} \mathrm{P}$-labeled oligonucleotide probes: one specific for HDV genotype I and the other for genotype III. These probes were chosen from within the 57bp region that codes exclusively large delta antigens. This region is well conserved within a given genotype but is highly divergent between genotypes. Between hybridizations, membranes were stripped by boiling in $0.1 \%$ SDS. Although there is some cross-hybridization because of the fact that the HDV genome, and therefore the hybridization probes, is very guanosine/cytosine (GC)-rich, genotypes can easily be inferred from the hybridization patterns (Figure 2). To validate the classification, two samples that were classed as genotype III and one genotype I sample were sequenced. Some samples can be typed at the RT-PCR stage, whereas others required the semi-nested PCR.

Statistical analysis. The qualitative or quantitative variables were analyzed using the following tests: qualitative variables were compared by nonparametric tests, by the $\chi^{2}$ test, or by the Mann-Whitney test as indicated. The Student $t$ test or correlation test was applied to the analysis of quantitative variables. Differences were considered to be significant when the probability $(P)$ of a type I error $(\alpha)$ was $\leq 0.05(5 \%)$. Considering that explicative variables and the response variable (HDV genotype) are categorized, the $\chi^{2}$ test was initially used to determine the correlation between these parameters. The chance ratios (95\% CIs) were calculated.

\section{RESULTS}

Among the 40 patients, 13 (32.5\%) were women and 27 (67.5\%) were men (Table 1). Genotype I was detected in 22 patients $(55.0 \%)$, whereas genotype III was identified in 18 $(45.0 \%)$. The mean age of all patients was $39.6 \pm 16.1$ years. Patients who were infected with genotype I were older (45.1 \pm 17.8 years) than patients infected with genotype III $(32.8 \pm$ 10.9 years $)$. This difference was statistically significant $(P=$ $0.01)$. Taking the median age to be 38 years, genotype I was present in $72.7 \%(N=16)$ of the patients $>38$ years and genotype III was present in only $27.8 \%(N=5 ; P=0.01)$.

Marginal statistical significance $(P=0.08)$ was observed when different age strata were compared: 11-20, 21-30, and > 


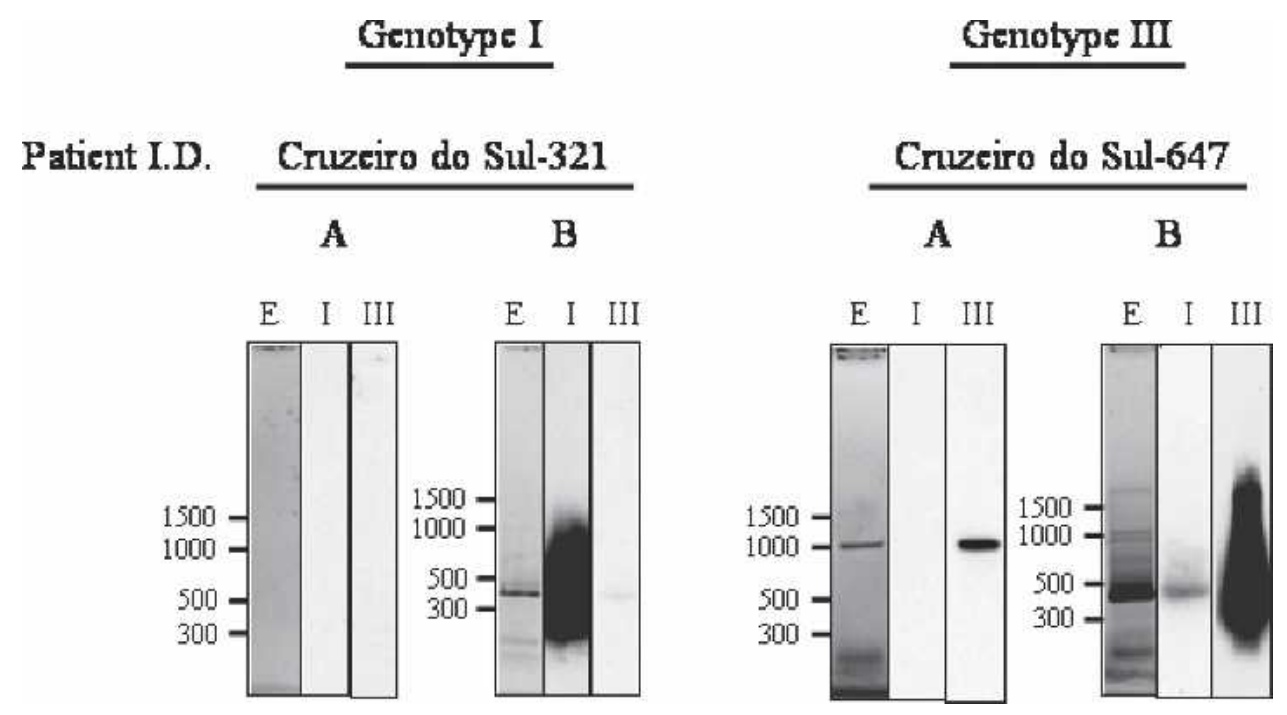

FIGURE 2. HDV genytyping by hybridization.

30 years (Table 1 ). We observed a bimodal distribution, with genotype I infections being predominant among patients from 11 to 20 and $>30$ years, whereas the vast majority of patients in the 21- to 30-year range was infected with genotype III.

No symptoms were reported by $21(52.5 \%)$ patients (Table $2)$. In these cases, the diagnosis of HDV infection was either incidental or was established because of the epidemiologic survey. Otherwise, 19 (47.5\%) had symptoms (fatigue, abdominal pain, weight loss, and decompensated liver disease) that motivated them to seek medical care. Although it is near the limit of statistical significance, patients infected with genotype III were more symptomatic. No differences were found concerning genotype and race or sex.

\section{DISCUSSION}

The Amazon region of Brazil has an area of 5.2 million square kilometers ( $61 \%$ of the Brazilian territory), but with a demographic density of only 3.67 inhabitants $/ \mathrm{km}^{2}$. In the last two decades, the region has been exposed to a demographic

TABLE 1

Demographic data according to HDV genotype group

\begin{tabular}{|c|c|c|c|}
\hline \multirow[b]{2}{*}{ Demographic parameters } & \multicolumn{2}{|c|}{ HDV genotype percent $(N)$} & \multirow[b]{2}{*}{$P$ value } \\
\hline & Genotype I & Genotype III & \\
\hline \multicolumn{4}{|l|}{ Sex } \\
\hline Male & $55.6 \%(15)$ & $44.4 \%(12)$ & \multirow{2}{*}{$0.05^{*}$} \\
\hline Female & $53.8 \%(7)$ & $46.2 \%(6)$ & \\
\hline \multicolumn{4}{|c|}{ Age (above and below median) } \\
\hline$<38$ years & $31.6 \%(6)$ & $68.4 \%(13)$ & \multirow{2}{*}{$0.01 \dagger$} \\
\hline$\geq 38$ years & $76.2 \%(16)$ & $23.8 \%(5)$ & \\
\hline \multicolumn{4}{|l|}{ Age strata } \\
\hline $11-20$ years & $66.7 \%(2)$ & $33.3 \%(1)$ & \multirow{3}{*}{$\begin{array}{r}>0.05 \\
(0.08)\end{array}$} \\
\hline 21-30 years & $23.1 \%(3)$ & $76.9 \%(10)$ & \\
\hline$>30$ years & $70.8 \%(17)$ & $29.2 \%(7)$ & \\
\hline \multicolumn{4}{|l|}{ Origins } \\
\hline Non-amerindian & $58.3 \%(21)$ & $41.7 \%(15)$ & \multirow{2}{*}{$0.05^{*}$} \\
\hline Amerindian & $25 \%(1)$ & $75 \%(3)$ & \\
\hline
\end{tabular}

expansion that led to a population growth of $128 \%$, but $40 \%$ of the population still lives in rural areas near the jungle. The hallmarks of this region are the difficult access and low social development indexes. Certainly, endemic diseases, such as viral hepatitis, may spread in this scenario.

HDV infection is under control in developed countries, but it is one of the most serious public health problems in the Brazilian Western Amazonia. ${ }^{13,14}$ Data from Brazilian Health authorities show that HBV/HDV infections in Amazonia must be considered a priority problem for public health, perhaps even more important than other tropical diseases such as malaria and yellow fever. ${ }^{15}$ Mortality rates caused by infectious diseases have declined during the last decade except for viral hepatitis (National Program for Viral Hepatitis Control, unpublished data). Although an ambitious vaccination program against HBV was implemented in this area in 1999, its impact on $\mathrm{HBV} / \mathrm{HDV}$ related mortality is still marginal. ${ }^{16}$ However, there are also particularities to HDV infection in this region that may also be part of the explanation for this situation and that merit closer study.

TABLE 2

Genotype distribution regarding race, age and sex in symptomatic or asymptomatic patient

\begin{tabular}{|c|c|c|c|}
\hline \multirow[b]{2}{*}{ Demographic parameters } & \multicolumn{2}{|c|}{ Clinical parameters percent $(N)$} & \multirow[b]{2}{*}{$P$ value } \\
\hline & Asymptomatic & Symptomatic & \\
\hline \multicolumn{4}{|l|}{ Sex } \\
\hline Male & $76.9 \%(10)$ & $23.1 \%(3)$ & \multirow{2}{*}{$<0.08^{*}$} \\
\hline Female & $40.7 \%(11)$ & $59.3 \%(16)$ & \\
\hline \multicolumn{4}{|c|}{ Age (above and below median) } \\
\hline$<38$ years & $52.6 \%(10)$ & $47.4 \%(9)$ & \multirow{2}{*}{$\mathrm{NS} \dagger$} \\
\hline$\geq 38$ years & $52.4 \%(11)$ & $47.6 \%(10)$ & \\
\hline \multicolumn{4}{|l|}{ Origins } \\
\hline Non-amerindian & $58.3 \%(21)$ & $41.7 \%(15)$ & \multirow{2}{*}{$<0.05$} \\
\hline Amerindian & $0(0)$ & $100 \%(4)$ & \\
\hline \multicolumn{4}{|l|}{ Genotype } \\
\hline I & $68.2 \%(15)$ & $31.8 \%(7)$ & \multirow{2}{*}{$<0.03 \S$} \\
\hline III & $33.3 \%(6)$ & $66.7 \%(12)$ & \\
\hline
\end{tabular}


The distribution of HDV is not uniform in the region, depending on social and geographic aspects (income distribution) and ethnic aspects (high prevalence among some Amerindian ethnic groups). Over the last 30 years, epidemics of fulminant hepatitis have been described in Western Amazonia. The hallmarks of these severe hepatitis cases are young age, high mortality, and peculiar histologic features with mild necro-inflammatory lesions but an abundant presence of ballooned hepatocytes with a central nucleus surrounded by microvesicular steatosis. Most cases were related to HBV/HDV co-infection or superinfection. ${ }^{17,18} \mathrm{HDV}$ infections have also been described in other Western Amazonia countries such as Peru, Venezuela, and Equator, ${ }^{7,19,20}$ also in isolated Amerindian populations. Cases of severe hepatitis in Peru and Venezuela have been correlated with infection by HDV genotype III. ${ }^{10,20}$ Genotype III is found only in Amazonia and was probably originally indigenous to the Amerindian population. However, HDV genotype I also exists in this region and may have been introduced during the rubber boom era, the first major contact between Indian and non-Indian populations. Studies have shown that familial transmission of HDV may occur through personal contact. ${ }^{21}$ In addition, malaria and other tropical diseases were treated with drugs dispensed using non-disposable syringes, which would increase the risk of dissemination of blood-borne viruses. This has been shown to be the case for spread of hepatitis $\mathrm{C}$ in Brazil. ${ }^{22}$

Many patients who were referred to the centers actually live in remote and difficult to access areas. Close follow-up of these patients and the identification of important points such as HDV transmission routes and the time of infection are therefore difficult. In general, the transmission routes have not been clearly identified. Transmission usually starts in early life through intrafamilial routes, but the risk factors involved are still unknown. ${ }^{23,24}$ The uncertainty concerning the time of infection must be taken into consideration when we interpret our results concerning the age of patients with genotypes I and III. The higher age observed in patients with genotype I could be related to longer-lasting disease, but apparently young patients who are carriers of genotype III had more symptomatic disease. This is an aspect that deserves further clarification.

Our preliminary data could not show a significant predominance of HDV genotype III among the native population, probably because of the low number of Amerindian patients involved. It is possible that native populations are not reaching the referral centers in Amazonia. Lower life expectancy in the native population must also be considered, mainly when age and genotype frequency are analyzed. On the other hand, our data are in agreement with the hypothesis that HDV genotype III is more pathogenic, because most carriers of this genotype, although younger, were symptomatic compared with genotype I carriers. Our data also show that genotype III infections have spread to the non-Indian population.

Biomolecular studies can help clarify why genotype III HDV infections seem to be more severe than those involving genotypes I and II. It has been suggested that genotype III large delta antigen, which requires editing of HDV RNA for its own production, can inhibit this RNA editing. ${ }^{25}$ This may result in the accumulation of large amounts of replicating HDV RNA and small delta antigen in the infected hepatocytes. This accumulation, along with interaction between
$\mathrm{HDV}$ and the co-infecting $\mathrm{HBV},{ }^{10,12}$ may result in direct hepatocellular damage.

In conclusion, our preliminary results show that delta hepatitis genotypes I and III are present in Brazilian Amazonia. These results warrant further epidemiologic studies involving larger numbers of patients from indigenous and nonindigenous populations, as well as the study of the role of HDV in the peculiar form of fulminant hepatitis observed in this region.

Received January 29, 2006. Accepted for publication April 7, 2006.

Financial support: This study was supported by post-graduate program association Federal University of Bahia and CAPES/ COFECUB Grant 404/02.

Authors' addresses: Raymundo Paraná, Av. Juracy Magalhaes Jr 2096, Sala 510, Salvador, Bahia 41920000, Brazil, Tel: (55) (0) 71 3537810, Fax: (55) (0) 71 3534980; E-mail: unif@svn.com.br. Alan Kay and Christian Trépo, INSERM U271, Université Claude Bernard Lyon 1, IFR 62, 151 cours Albert Thomas, 69003, Lyon, France, E-mails: kay@lyon.inserm.fr and trepo@lyon.inserm.fr. Felix Molinet and Pedro Tauil, Nucleo de Medicina Tropical, University of Brasilia, Campus Universitário, Brasilia-DF 70000000, Brazil, E-mail: tropical@unb.br. Sebastião Viana, Government of Acre State-Health Secretariat, avenue Getúlio Vargas 1446, Rio Branco-AC 69908650, Brazil, E-mail: viana@senado.gov.br. Luciano Kalabric Silva, José Tavares-Neto, Márcio Rios-Leite, Luciana Matteoni, and Argemiro D' Oliveira Jr, Gastro-Hepatology Unit, HUPES, Centro de Pesquisa Gonçalo Moniz, rua Pasre Feijo 240, 30 piso, Salvador-BA 40130150, Brazil, E-mail: petmedicina@yahoogrupos.com.br. Juan Miguel Salcedo and Cirley Lobato, Centro de medicina Tropical, rua Guaporé 215, Porto Velho-RO 78909350, Brazil, E-mail: unif@syn.com.br.

\section{REFERENCES}

1. Rizzetto M, Canese M, Aroci S, Crivelli O, Trépo C, Bonino F, Verme G, 1977. Immunofluorescence detection of a new antigen-antibody system (Delta/anti-Delta) associated with hepatitis B virus in liver and serum of HBsAg carriers. Gut 18: 997-1003.

2. Gaeta GB, Stroffolini T, Chiaramonte M, Ascione T, Stornaiuolo G, Lobello S, Sagnelli E, Brunetto MR, Rizzetto M, 2000. Chronic hepatitis D: A vanishing disease? An Italian multicenter study. Hepatology 32: 824-827.

3. Bensabath G, Hadler SC, Soares MC, Fields H, Dias LB, Popper H, Maynard JE, 1987. Hepatitis delta virus infection and Labrea hepatitis. Prevalence and role in fulminant hepatitis in the Amazon Basin. JAMA 258: 479-483.

4. Bensabath G, Dias LB, 1983. Labrea hepatitis (Labrea black fever) and other fulminant forms of hepatitis in Sena Madureira. Rev Inst Med Trop Sao Paulo 25: 182-194.

5. Fonseca JC, Simonetti SR, Schatzmayr HG, Castejon MJ, Cesario AL, Simonetti JP, 1988. Prevalence of infection with hepatitis delta virus (HDV) among carriers of hepatitis B surface antigen in Amazonas State, Brazil. Trans R Soc Trop Med Hyg 82: 469-471.

6. Fonseca JC, 2002. Hepatitis D. Rev Soc Bras Med Trop 35: 181190.

7. Casey JL, Brown TL, Colan EJ, Wignall FS, Gerin JL, 1993. A genotype of hepatitis D virus that occurs in northern South America. Proc Natl Acad Sci USA 90: 9016-9020.

8. Chao YC, Chang MF, Gust I, Lai MM, 1990. Sequence conservation and divergence of hepatitis delta virus RNA. Virology 178: 384-392.

9. Radjef N, Gordien E, Ivaniushina V, Gault E, Anais P, Drugan T, Trinchet JC, Roulot D, Tamby M, Milinkovitch MC, Deny P, 2004. Molecular phylogenetic analyses indicate a wide and ancient radiation of African hepatitis delta virus, suggesting a deltavirus genus of at least seven major clades. $J$ Virol 78: 2537-2544.

10. Casey JL, Niro GA, Engle RE, Vega A, Gomez H, McCarthy M, Watts DM, Hyams KC, Gerin JL, 1996. Hepatitis B virus (HBV)/hepatitis D virus (HDV) coinfection in outbreaks of acute hepatitis in the Peruvian Amazon basin: The roles of 
HDV genotype III and HBV genotype F. J Infect Dis 174: 920-926.

11. Shakil AO, Hadziyannis S, Hoofnagle JH, Di Bisceglie AM, Gerin JL, Casey JL, 1997. Geographic distribution and genetic variability of hepatitis delta virus genotype I. Virology 234: $160-167$.

12. Quintero A, Uzcategui N, Loureiro CL, Villegas L, Illarramendi X, Guevara ME, Ludert JE, Blitz L, Liprandi F, Pujol FH, 2001. Hepatitis delta virus genotypes I and III circulate associated with hepatitis B virus genotype F In Venezuela. $J$ Med Virol 64: 356-359.

13. Braga WS, Brasil LM, de Souza RA, Castilho Mda C, da Fonseca JC, 2001. The occurrence of hepatitis B and delta virus infection within seven Amerindian ethnic groups in the Brazilian western Amzon. Rev Soc Bras Med Trop 34: 349-355.

14. de Paula VS, Arruda ME, Vitral CL, Gaspar AM, 2001. Seroprevalence of viral hepatitis in riverine communities from the Western Region of the Brazilian Amazon Basin. Mem Inst Oswaldo Cruz 96: 1123-1128.

15. Ribeiro LC, Souto FJ, 2000. Hepatitis Delta in the State of Mato Grosso, Brazil: report of 5 cases. Rev Soc Bras Med Trop 33: 599-602.

16. Tavares-Neto J, Almeida D, Soares MC, Uchoa R, Viana S, Darub R, Farias E, Rocha G, Vitvitski L, Parana R, 2004. Seroprevalence of hepatitis B and C in the Western Brazilian Amazon region (Rio Branco, Acre): A pilot study carried out during a hepatitis B vaccination program. Braz J Infect Dis 8: 133-139.

17. Fonseca JC, Ferreira LC, Brasil LM, Castilho Mda C, Moss R, Barone M, 1992. Fulminant Labrea hepatitis-the role of hepatitis A (HAV), B (HBV), C (HCV), and D (HDV) infection (preliminary report). Rev Inst Med Trop Sao Paulo 34: 609-612.
18. Andrade ZA, Lesbordes JL, Ravisse P, Parana R, Prata A, Barberino JS, Trepo C, 1992. Fulminant hepatitis with microvesicular steatosis (a histologic comparison of cases occurring in Brazil-Labrea hepatitis-and in central Africa-Bangui hepatitis). Rev Soc Bras Med Trop 25: 155-160.

19. Manock SR, Kelley PM, Hyams KC, Douce R, Smalligan RD, Watts DM, Sharp TW, Casey JL, Gerin JL, Engle R, AlavaAlprecht A, Martinez CM, Bravo NB, Guevara AG, Russell KL, Mendoza W, Vimos C, 2000. An outbreak of fulminant hepatitis delta in the Waorani, an indigenous people of the Amazon basin of Ecuador. Am J Trop Med Hyg 63: 209-213.

20. Nakano T, Shapiro CN, Hadler SC, Casey JL, Mizokami M, Orito E, Robertson BH, 2001. Characterization of hepatitis D virus genotype III among Yucpa Indians in Venezuela. J Gen Virol 82: 2183-2189.

21. Niro GA, Casey JL, Gravinese E, Garrubba M, Conoscitore P, Sagnelli E, Durazzo M, Caporaso N, Perri F, Leandro G, Facciorusso D, Rizzetto M, Andriulli A, 1999. Intrafamilial transmission of hepatitis delta virus: Molecular evidence. J Hepatol 30: $564-569$.

22. Parana R, Lyra L, Trepo C, 1999. Intravenous vitamin complexes used in sporting activities and transmission of HCV in Brazil. Am J Gastroenterol 94: 857-858.

23. Viana S, Parana R, Moreira RC, Compri AP, Macedo V, 2005. High prevalence of hepatitis $B$ virus and hepatitis D virus in the western Brazilian Amazon. Am J Trop Med Hyg 73: 808814

24. Parana R, Almeida D, 2005. HBV epidemiology in Latin America. J Clin Virol 34 (Suppl 1): S130-S133.

25. Cheng Q, Jayan GC, Casey JL, 2003. Differential inhibition of RNA editing in hepatitis delta virus genotype III by the short and long forms of hepatitis delta antigen. J Virol 77: 7786-7795. 